\title{
Democratic Transition and Crime in Nigeria
}

\author{
Adigwe, Felix Azogu
}

\begin{abstract}
Change is a constant feature of every society. Some changes are gradual barely unnoticed while some are radical, turbulent and conflictual. Some consequences of these changes are sometimes unintended, unforeseen and unplanned for. These types present more challenges to societies. It has been established that societies in transition are usually faced with certain challenges; crime and violence being some of them (see: Nedcor, 1996, Zveki,c 1998, Savelsberg, 1995, Crilinskiy, 1998)

This study seeks to certain the nature and level of crime and violence that Nigeria has witnessed since the inception of her democratic transition. Nigeria embarked on democratic transition in 1998 after about sixteen years of military rule. The period of the democratic transition witnessed an upsurge in violent and criminal acts across the country. These manifested in different guises such as religious and ethnic conflicts, militant agitations and so on.

Could this increase in crime rate and violence be associated with the democratic transition? This study sought to answer this question.
\end{abstract}

Key words: Transition, Crime and Democratisation

\section{Introduction}

High crime rates in transiting societies have drawn the attention of criminologists and criminal justice researchers. Researchers linking political transition (and related economic and social transformation) to crime have been carried out in countries undergoing transition.

Transition from totalitarian, dictatorial or one-party state to liberal democracy has been reported to generate unanticipated upsurge in crime.

According to Peter Blau and W. Scott;

Change whether due to new external developments impinging on the organization or to internal modifications, produces situations without precedents. Besides, some exigencies that may arise cannot be anticipated.

In Nigeria, the change from military dictatorship to civilian democratic rule was sudden following the demise of the Head of the military junta; Gen SaniAbacha. The Former Minister for Police Affairs General David Jemibewon in an opening address presented at a conference in South Africa acknowledged that;

The sudden change which the transition from long years of military rule to a democratic dispensation brought on the country (Nigeria) was so monumental and managing it was daunting.

He went further to say that;

The Nigerian Police that ... our new found democracy became to some extent a source of insecurity and lawlessness, as rights were misconstructed and exercised without restraints, views which were considered anti-government and hitherto suppressed out of fear under the military, were now freely expressed and often times violently too. Militants groups agitating for one thing or the other often times armed sprang up in some parts of the country. The Police which was not adequately prepared for the violent and criminal eruptions that heralded our democratic rebirth was therefore stretched to the maximum of their capability.

Militants groups sprang up across the country with ethnic connotation. The violent clashes across the country and rising criminal acts that were witnessed in the country startled the government. The Police Force which has the legitimate authority to contain these problems was not prepared. They lack the capacity to cope in the new situation. This was as a result of the long neglect during the military rule. The Military Regimes had in place repressive security outfits that were headed by the military men. They were better equipped and motivated. However, with the assumption of office by the civilian government (states and federal) those military security outfits were demobilized as part of the democratic change. These then created a gap between the legitimate effort to reform and the capacity to cope in the new situation. 


\section{Government and Public Responses to the Increasing Crime}

Democratic euphoria usually accompanies every new democracy. Public expectations from the new government are usually high. The government usually makes promises of addressing all the people's problems and concerns. This was the case in Nigerian when the civilian government was sworn in on May $29^{\text {th }}, 1999$.

However, it did not take long for the indices of insecurity to manifest in the country. The country during this period recorded some violent clashes. Crime such as armed rubberylbanditry, assassination $\backslash$ premeditated killings, including extra-judicial killings received wide media attention. There were also violent ethno-religious clashes that resulted to wanton destruction of lives and properties. The Niger Delta Region became the hotbed of youth restiveness. The spate of ethnic, religious and communal clashed across the country was unprecedented in frequency in the history of the country. The agitation of Niger Delta Region youthsbecame more restive as they engaged in the act of abducting and hostage taking of oil company workers and expatriates and blowing up of oil facilities in the area. Violence was becoming a regular occurrence in the country. Many lives and properties were lost as ethnic militiamen unleashed terror on the people across the country.

Religious crises occurred in Kaduna and other northern parts of the country following the introduction of Sharia legal code. This sparked off reprisal killings in the eastern parts of the country. Youths in Odi, Bayelsa state abducted and killed 12 policemen. In Benue state, Tiv militiamen also killed some soldiers that were sent on peace keeping mission in the area following inter-communal clashes. The Federal government responded by deploying the military to the areas to contain the crises and safeguard the democracy. The government torn between the need to erect and maintain constitutional bulwarks against authoritarianism and the apparent danger that the spate of ethnic, religious and inter-communal clashes, the activities of the ethnic militiamen and armed banditry resorted to the use of authoritarian approach. The government gave the police a shoot at sight order against the members of Odua People's Congress (OPC) and other ethnic militia involved in one agitation or the other. The government had to use the military in quelling civil disturbances. The incidences in Odi, Bayelsa state and Zarki-Biam in Benue state showed government disproportionate' response which was devastating. The Human Right Watch International accused the federal government of violating human rights by unlawful detention. The group also maintained that the number of people in detention in the country is beginning to rise (see Human Right Report, April 2003). This has resulted in the return of congestion in our prison after the brief period of success at decongesting the prisons. The government had drawn up a four year development plan for the police. The plan focused on improvement in law enforcement. As part of the plan, the Nigerian Police have embarked on the recruitment of about 40,000 police personnel. By the end of the $5^{\text {th }}$ year, the ratio of the police to the population will shift from the current (1:714) one police office to seven hundred and fourteen people (1:294) one police office to two hundred and ninety four people. The public faced with the problem of crime, in security and increasing social disorder had taken different measures to enhance their security. According to Shaw (2002);

Establishment of liberal democracy brings paradoxical forces into play in most transitional societies. On the one hand, the conditions for the growth of crime are enhanced, on the other; citizens look (as they have never done before), to the state for protection. Given the very real constraints on the post-transition state in delivering effective systems of criminal justice (such as low skill levels, lack of representative institutions and poor resourcing) citizens are likely, over time, to seek alternative forms of protection such as vigilantes and for the wealth (including the business sector), the increases the privatization of policing and crime prevention.

This is the situation in Nigeria as the first few years of the civilian rule has witnessed the proliferation of the militant vigilante groups and private security companies. Some of the rich people in response to the insecurity situation in the country installed Closed Circuited Television (CCTV) in their homes fix bullet proof doors, erect high walls around their houses and hire the services of private security outfits to guard their homes. Some even keep dogs trained for guarding.

Many communities have formed vigilante groups to protect themselves and their properties. These measures are in the bid to address the insecurity prevailing in the country. The formation of the Bakassi Boys, a militant vigilante group in Aba and Onitsha was in response to the high crime incidences in those commercial cities.

\section{Criminal Trend In Nigeria}

Crime is a permanent feature of every society (Durkheim, 1950). According to Durkheim, crime poses a threat to society when it is high, otherwise crime bring about change in society. Media reports indicate that Nigeria is undergoing an unprecedented wave of violence in the form of assassinations, ritual murders, ethnic/religious clashes and armed robbery, a staggering level of official corruption, police collusion with criminals and actual involvement in criminality (Ahire, 1983:36). This shows that crime trend in the country has been changing. Crime character is assuming new dimensions. According to Ahire (1988); 
Recent developments have revealed that the robbers of the late eighties are no longer what they used to be. There is clear indication that the organization methods, weaponry, target and attitudes of robbers are undergoing a progressive metamorphosis in keeping with change in the overall society.

In keeping to this progressive metamorphosis crime in the late nineties and in the new millennium is changing also in organization, methods, weaponry, target and attitudes. The instability within the sub-region had lead to the proliferation small arms and light weapons (SMLW). The Nigerian boarders are porous. Armed bandits from neighboring countries have been invading the northeastern parts of the country. These are said to be rebel soldiers from Chad and Niger. According to reports, these bandits are usually armed with automatic riffles like AK 47, pump action guns, machetes, bows and arrows. They are said to be brutal in their attacks as the usually kill their victims. They raid isolated communities and mount road-blocks in some cases.

There is a reported shift in robbery attacks within the metropolis in the country. There are certain types of robbers that are referred to as "graduate-robbers".

Their targets usually are the rich and influential members of the society, commercial banking institutions and other high profile targets.

Crimes such as Human trafficking and child slavery have gained wide reportage in the media within the few years of civilian rule. There is an organized crime groups with international links that specialize in taking young Nigerian girls and boys to foreign countries for prostitution and slave labour. Militant ethnic groups have emerged across the country also. Most of them display flagrant disrespect to law and authority. In Niger-Delta, the militant youths engage in the act of abducting and taking hostage of oil company workers, they demand ransom before they release their hostages. The militant vigilante group the Bakassi Boys is becoming a law to themselves as they arrest, detain and extra judicially execute"criminals". They also intervene in civil matters such as being used by landlords to collect rent or evict a tenant, recover debts settling of disputes and in some instances used by politicians to settle scores.

\section{Research Problem}

Transitional societies have been linked to high crime incidences. Nigeria's transition from long period of military rule to civilian rule has witnessed the increased violent crimes. Between May 29, 1999 and January 2993, the country witnessed over (34) thirty-five ethnic, religious and Communal violent clashes. These clashed left thousands dead and properties worth millions destroyed or burnt. These violent clashes cut across the country. There has been wide and frequent media report of crime across the country. These reports are giving the impression that crime is on rapid increase in the country. The public has responded to this situation by forming vigilante groups. There has been a proliferation of vigilante groups (some of which are very militant) and private security companies in response to the demands for safety and security by the citizens. The former Minister of Police Affairs acknowledged this when he said;

... our new found democracy became to some extent a source of insecurity and lawlessness ... Militant group that were agitating for one thing or the other, often times armed, sprang up in some parts of the country.

The police... was not adequately prepared for the violent and criminal eruptions that heralded our democratic rebirth ... (Jemibewon, 2001, quoted in Equal Justice, Vol. 4 No 11 April, 2002).

The Minister in the address acknowledged the rapid rise of crime in Nigeria and the inadequacy of the State Security agency to contain the problem. The ill-preparedness of the police to provide security for the citizens compelled them to seek for alternative means of protecting their lives and properties. The poor bond together in the formation ofvigilante groups, while the rich the services of private security or the police to secure them and their properties. This is an illusion of one of the fundamental myths of modern society "that the sovereign state is capable of providing security, law and order and crime control" (British Journal of Sociology, Vol. 47 No 1, March 1996).

Tacit support and patronage were given to this vigilante groups in some states. The Bakassi Boy's vigilante groups that originated in Aba were later introduced into Anambra State due to its perceived success in scaling down the activities of criminals in Aba. Other ethnic militants that were originally formed to champion political causes added to their objective; crime fighting. They include the OduaPeoples Congress (OPC). These militant vigilante groups with time became "law" in themselves. The government perceived them and their activities as threats to the democracy, the unity of the country and an admission of its failure in carrying out one of its primary responsibilities. Their activities was becoming a menace and the government in trying to regain control and cut their excesses issue a shoot at sight order to the police against members of the OPC and other ethnic militias. Assassinations have been witnessed across the country since 1999 among the prominent Nigerians assassinated were Anthony Ikhazabor, Lai Balogun, Chris Ogunjobi, Chief Bola Ige, Chief Harry Marshal, Hon. OduneyoOlagbaju, Chief Victor Nwankwo, Barr. BanabasIgwe and his wife, AlhajiUsmanPategi, Chief OgbonnayaUche, and several others. 
Thuggery and political clashes were recorded in 2002 at Eto Baba area of Jos, Plateau State between two PDP factors that left 70 people dead and about 60 vehicle burnt. In Kano State Obasanjo's campaign office was burnt down by irate youths that also attacked Vice President AtikuAbubakar when in Kano. In Warri, Dalta State thugs at PDP rally confronted students of Petroleum Training Institute leaving 16 students dead. In Agwa, a community in Imo State irate youths attacked and disrupted the commissioning of some projects by the Governor in 2002 in that community. Thugs also killed an All People Party (APP) chairman's wife and his two children in Bassambiri, Bayelsa State. In Oron, Akwalbom State, irate youths besieged a police Station and beheaded the divisional Police Officer (DPO). These incidences took place before February/April 2003 general election in the country. In responding to the crime problem in the country, the Nigerian Police embarked on yearly recruitment and training of officers to contend with violence and combat the raising crime in the country.

In the April 2003 presidential election, security and safety were some of the major campaign promises of the aspirants. The aspirants were responding to the problem of insecurity and safety in the country.

Has Nigerian transition to democracy led to increase in crime rate? And if so, why do we have rising crime rate during transition?

\section{Purpose And Objectives Of The Study}

The major objective of this study was to examine the relationship between democratic transition and crime in Nigeria. Specifically, the study was designed to examine the pattern of crime during the democratic transition. Under this objective, the study sought to find out the types of crimes that have high frequency during the democratic transition. That is to say, which type of crime could be associated with democratic transition in Nigeria? This is under the assumption that certain types of crimes are committed more often during political transition, than at other times (Dixon, 2002).

\section{Theoritical Framework}

This work used two theoretical approaches: The conflict approach and the strain theories. These two approaches aches are complementary.

\section{STRAIN THEORY}

This is a cluster of perspectives that view criminality from outside of the individual. They argue that the impulse to commit crime is normal and socially induced.

It means that crime is socially determined. Though the individual is a rational problem solving entity, yet he/she is placed in determined frameworks. The individual is inculcated with "culture goals and with range of appropriate means and opportunities of achieving them. It is within this framework that the individual makes choices and decisions to solve particular problems he/she faces.

It posits that people are socialized into consensus of values, which corresponds to the needs of the social system. They also recognize dysfunctions that may arise from the functioning of the system. The same system that socializes individuals to acceptable goals creates structures that make it impossible for certain categories of individual to gain access to the means. To exist poverty lower class families struggle to send their children to school and better their chances. However, the lack of job opportunities due the disproportionate job opportunities and the numbers of graduates being turned out of our universities brings disillusion and frustrations that can induce deviant behavior.

The theory maintains that the means by which an industrial society maintains itself creates the circumstances by which wide range of disorder occurs. The fast technological breakthroughs and developments reduce the dependant on humans, thereby creating unemployment through retrenchments, rationalization, downsizing and so on.

It also maintains that the lower class people experience blocked opportunities to the shared cultural goals more than the upper class individuals hence their representation in crime and deviance. Income determines a lot of things; the quality of education your children can receive, the quality of medical care that they can receive, the level of exposure, and their chances of success in life.

The people at the lower income bracket are limited due to a lot of factors tied to their income level. 'The substantive inequalities of wealth give rise to frustration and deviance among the poor'. ' Deviance is seen to be the result of a dysfunction between the culturally induced aspirations of individuals and the structurally determined opportunities. When we consider happiness, it is also tied to how much of the materials wealth one can afford. Ambition promotes deviation when it is institutionally frustrated. They went further to say that this dysfunctions arising from unfulfilled culturally set goals are not only experienced by isolated individuals but also the whole groups of individuals in certain structural positions. The high representation of the poor and middle class families in crime highlights this. The bulk of the youths that make up these militant groups come from these two classes. 
The variants include Merton's theory of Middle Range", Cohen (1972), Cloward and Ohlin (1964), Matza (1969). They advocate the reformation of the structure of society so as to allow for more egalitarian opportunity structure.

The strain theory has been criticised as focusing on the lower class people's crime.

Also it has been accused of denying the existence of pluralism of value. The idea of a consensus in value is not entirely true. Young (1981) puts it thus:

Such a position considerably underestimates the rational undermining of accepted value and legitimate procedure, which constantly occurs; negotiation of values cross-cuts inmeans, reinterpretation of goals, cynical conformity, distancing of commitment etc.

It does not address the origin of the existing system. Therefore it has been accused of having class bias. However this theory addresses specific crimes, such as group or gang deviance. It also addresses different responses of individuals or group when facing the blocked opportunities in the system. There are crimes that can be seen as economically induced and some as culturally determined.

We are well aware of the shortcomings of this theoretical perspective but we believe that it will best explain the study.

\section{Methodology}

This study made use of primary and secondary data. The primary data came through interviews and questionnaire. This study covers a certain period of time that is 1996-2003. The period from 1996-1998 are taken as pre-democratisation/election period while from 1998-2003 are taken as the democratization period. The dependant variable is crime (the various types of crime as outlined earlier) while the independent variable is democratization. Democratization in this case embraces the opening up of the political space to the conduct of the election proper. By this we mean the lifting of the ban placed on political activities, this leads to the formation of the political associations, formation of political parties and their registration, politicking up on till the actual elections.

Transition is an event that has to do with change in the social system. It is important to conceptualize this word transition. The scientific understanding of transition centers on three broad theories. One of these theories places emphasis on the political and institution processes behind shift from authoritarian to democratic rule. The second perspective focuses on the evidence of the modern social and economic conditions that are believed to be associated with democracy. The third school of thought sees the changing structure of class, state and transitional power as the main motor of democratic change.

In their studies of transition in Africa, MichealBrathon and Nicolas Van de Walle (1997:13) argue that

(A) Transition to democracy occurs with the installation of a government chosen on the basis of competitive election, as long as the election is freely and fairly conducted within a matrix of civil liberties and all the contestants accept the validity of the election results. (Quoted in Dixon, 2002:6)

In our search for explanation for the change, we went beyond the confines of the political to the wider social, economic and structural origins.

\section{Sources of Data Collected}

\section{Method Of Data Collection}

Two principle sources were used in obtaining the data for this research. They are the secondary and primary sources. The secondary sources were; documentary which comprised of records from the Nigerian Police, the newspapers and magazines reports, records from the local vigilante, while the primary sources were questionnaire and focus group discussion (FGD).

\section{Method Of Data Analysis}

In analyzing the data collected in this study, the researchers made use of sample percentage, tables. Also the descriptive method was employed in the presentation of finding.

\section{Method Of Data Analysis}

In analyzing the data collected in this study, the researchers made use of sample percentage, tables. Also the descriptive method was employed in the presentation of finding. Direct quotations from respondents in some instances were used. Also the type of questions asked by the researchers made the researchers to adopt the method. 


\section{Findings/ Discussion}

In presentation of the data from this work, we used simple percentage table.

Crime Profile in Nigeria from 1993

Below is the statistics presentation of crime profile in Imo State between 1993-1997.

Table 4.1a: Comparative table on most prevalent offences against persons 1996 and 1997.

\begin{tabular}{|c|c|c|c|c|c|c|c|c|}
\hline $\begin{array}{c}\text { State } \\
\text { Imo }\end{array}$ & Murder & $\begin{array}{c}\text { Grievous } \\
\text { Harm and } \\
\text { wounding }\end{array}$ & Assault & Armed & $\begin{array}{c}\text { Theft and } \\
\text { Stealing } \\
\text { House }\end{array}$ & $\begin{array}{c}\text { House } \\
\text { Breaking }\end{array}$ & $\begin{array}{c}\text { False } \\
\text { Pretence }\end{array}$ & $\begin{array}{c}\text { Unlawful } \\
\text { Possession }\end{array}$ \\
\hline & 32 & 161 & 1948 & 55 & 3,495 & 239 & 178 & 193 \\
\hline
\end{tabular}

Table 4.1b comparative Table on offences in Imo State between 1994 - 1997 and 1999 - 2003

\begin{tabular}{|l|l|l|l|l|}
\hline \multicolumn{1}{|c|}{ Offences } & $\mathbf{1 9 9 4} \mathbf{- 1 9 9 7}$ & $\mathbf{1 9 9 9 - 2 0 0 3}$ & \% Increase & \multicolumn{1}{c|}{ Remark } \\
\hline Robbery & 97 & 156 & 23 & Increase \\
\hline Murder & 64 & 121 & 31 & Increase \\
\hline Burglary & - & - & - & - \\
\hline House Breaking & 562 & 8821 & 88 & Increase \\
\hline Stealing & 14606 & 23421 & 23.2 & Increase \\
\hline Kidnapping & 15 & 15 & 50 & Steady \\
\hline Child Stealing & 1 & - & - & Decrease \\
\hline Arson & 14 & 54 & 58.82 & Increase \\
\hline Rape & 27 & 31 & 6.9 & Increase \\
\hline False Pretence & 178 & 104 & 26.2 & Decrease \\
\hline Unlawful Possession & 193 & 287 & 19.6 & Increase \\
\hline Grievous Harm \& Wounding & 161 & 301 & 30 & Decrease \\
\hline
\end{tabular}

Source: Police Annual Report 1993 - 2002

The Table 4.2 above shows that crime rates increased during the transitory years. Only false pretence showed a decline. Robbery rate rose by $23 \%$. Arson rose by $62.5 \%$. From the table we can see that certain crimes showed remarkable increase. These type of crimes have been associated with transitory periods in other countries; include; rape, burglary, robbery, murder, and house breaking (See Nedcor, 1996, shaw 1995, Schonteich and Louw, 2001, Zvekic, 1998, Alvazzi del Frate, 1998, Savelsberg, 1995, Gilinskiy, 1998).

Democratization in the country was ridden with tensions and upheavals and these can indeed contribute to the high and rising levels of crime during these years. The anomie and strain theories of crime explain crime under conditions of radical social change like transition. Savelsbery, 1995: maintain that radical transformations are never smooth processes (P.207) He argued that "Popular expectations are unspecific and rarely realized.

Capitalization dose not make everyone wealthy. On the contrary, it may make people poorer and widen the gap between rich and poor ... Democracy itself can turn out to be a complicated and often frustrating process". This situation is not far from the Nigerian experience. Hopes and expectations of majority of Nigerians have been dashed and they are disappointed. Out of the frustration, some individuals may turn to deviance behavour, crime and delinquency. The political transition generated substantial material expectations in the people, (as dividends of democracy) who have been groaning under the yoke of the Structural Adjustment Programme (SAP) and the imposed sanctions during the military regime of late Gen. SaniAbacha. These expectations are largely beyond the immediate delivery capacity of the new government. Peace forums and talk shops that have been organized in the country since the inception of the present democratic government have tried to appeal to the masses especially the youths to exercise more patience with the government in delivering the democratic dividends.

Table 4.1c Crimes victims and Distribution from 1999-2003.

\begin{tabular}{|c|c|c|c|c|c|c|c|}
\hline Crime & No of victims & 1999 & 2000 & 2001 & 2002 & 2003 & Total \\
\hline Robbery & 51 & 9 & 16 & 14 & 17 & 9 & 116 \\
\hline Burglary & 28 & 20 & 21 & 32 & 11 & 7 & 119 \\
\hline $\begin{array}{l}\text { House } \\
\text { breaking }\end{array}$ & 15 & 14 & 7 & 10 & 24 & 5 & 75 \\
\hline Stealing & 30 & 25 & 25 & 30 & 7 & 10 & 127 \\
\hline Kidnapping & 2 & 1 & - & - & 3 & - & 6 \\
\hline Arson & 5 & 1 & - & - & 3 & - & 9 \\
\hline $\begin{array}{l}\text { Grievous } \\
\text { blame } \quad \& \\
\text { wounding }\end{array}$ & 5 & 5 & 1 & 1 & 10 & 1 & 23 \\
\hline Assault & 25 & 10 & 5 & 4 & 17 & 2 & 63 \\
\hline
\end{tabular}


The above table brings out the distribution of the crimes committed against the victims over the years. And we can see from the table that the crime like robbery rose after 2000. This was the year following the general election of 1999. Burglary showed steady rise but declined from 2002. High rates of kidnapping proceeded the elections years. And some of the respondents denied being involved in active politics. Arson was highest I 2002, the same year assault recorded highest rise.

We can see from the above tables that some crimes increased in the years that preceded the elections while some increased after the elections.

*Again below we present the statistics of some crimes by States across the country in 1994*

\section{Crime Profile In The Transitory Years.}

With the commencement of the transition to democratic rule, crime burst was witnessed across the country as preparations and attentions shifted on the democratic transition, the criminals seized on the opportunity to carry out their acts with little hindrances. There were reports of increased activity of ritual killings, kidnapping, assassination, human trafficking and armed robbery attacks. According to the report released by Pro-Human Right Group based in Kaduna; Civil Rights Congress, 83 persons were killed while about 159 persons were injured in twelve States during the April elections. Below is a table showing the States and the number of persons killed or injured.

Table 4.3a States And Number of Persons Killed or Injured in the April Election 2003.

\begin{tabular}{|l|l|l|}
\hline \multicolumn{1}{|c|}{ STATE } & \multicolumn{1}{c|}{ KILLED } & \multicolumn{1}{c|}{ INJURED } \\
\hline Bayelsa & 21 & - \\
\hline Benue & 19 & 33 \\
\hline Delta & 25 & - \\
\hline Kano & 3 & 7 \\
\hline Kebbi & 1 & 17 \\
\hline Kogi & 7 & 16 \\
\hline Nassarawa & 3 & 15 \\
\hline Total & 79 & 88 \\
\hline
\end{tabular}

Sources: Civil Right Congress Report, 2003.

Below is the presentation of some cases of armed robbery and assassination incidences across the country between Januarys to December 2000.

Table 4.3b. Some Assassination, Armed Robbery, and Killings from January - December 2003.

\begin{tabular}{|l|l|l|}
\hline \multicolumn{1}{|c|}{ Names/Place } & \multicolumn{1}{|c|}{ Details } & \multicolumn{1}{|c|}{ Date } \\
\hline AlhajiMukailaOkunade Petrol dealer in Lagos & Assassination & Jan 2000 \\
\hline AkwahiAlhaji Road FCT & 9 people were killed by robbers during an operation & Feb., 2000 \\
\hline $\begin{array}{l}\text { Mag. Gen. David Jemibewon. (Rtd) Minister For Police } \\
\text { Affairs (then) }\end{array}$ & $\begin{array}{l}\text { His guars was killed when robbers attacked his } \\
\text { residence }\end{array}$ & Feb.,2000 \\
\hline $\begin{array}{l}\text { Igwe Francis Nwankwo, Traditional Ruler of } \\
\text { NowfiaNijikoka L.G.A. Anambra }\end{array}$ & Assassination & Feb., 2000 \\
\hline Godfrey Otubu, Leader of C.+5 Church & Survived robbery attack & March, 2000 \\
\hline Jennifer Madike (Society lady) & Survived robbery attack & March, 2000 \\
\hline $\begin{array}{l}\text { Maj. OmololaAjidayo } \\
\text { Chucks Ojema-Texas-based Nigerian car dealer }\end{array}$ & $\begin{array}{l}\text { Shot deed by robbers along with her house boy in } \\
\text { her residence }\end{array}$ & April, 2000 \\
\hline Deepak Mahtar, Indian & Shot several times by robbers but survived attack & April 24, 2000 \\
\hline Alakuko Police Station & Shot dead by robbers & Nov. 5, 2000 \\
\hline $\begin{array}{l}\text { Panti Police Station/Adekunle Police Station } \\
\text { Police corporal shot dead by robbers }\end{array}$ & $\begin{array}{l}\text { Robbers snatched two Mercedes Benz cars while } \\
\text { firing indiscriminately into the Station }\end{array}$ & Nov. 21, 2000 \\
\hline GadefeAyele, Ethiopian and WHO consultant & $\begin{array}{l}\text { Gadafe was wounded by robbers while his driver } \\
\text { was killed }\end{array}$ & Dec. 3, 2000 \\
\hline Chief Layi Balogun0yaba & Killed by robbers & Dec. 7, 2000 \\
\hline $\begin{array}{l}\text { Bor. \& Mrs. Igwe President Nigerian Bar Association, } \\
\text { Anambra Chapter }\end{array}$ & $\begin{array}{l}\text { Murdered by people believed to be members of } \\
\text { Bakassi Boys }\end{array}$ & 2002 \\
\hline
\end{tabular}


Democratic Transition and Crime in Nigeria

\begin{tabular}{|l|l|l|}
\hline \multicolumn{1}{|c|}{ Names/Place } & \multicolumn{1}{|c|}{ Details } & Date \\
\hline $\begin{array}{l}\text { Chief Bola Ige, Attorney Gen. of the Fed. \& } \\
\text { Minister of Justice. }\end{array}$ & Murdered in his house & 2002 \\
\hline $\begin{array}{l}\text { Chief ogbonnayaUche former } \\
\text { Commissioner Imo State \& Senatorial } \\
\text { Aspirant }\end{array}$ & Murdered in his house in Owerri & 2002 \\
\hline $\begin{array}{l}\text { Chief Hory Marshal, ANPP Dep. Chairman } \\
\text { South-South }\end{array}$ & Murdered in his house in Abuja. & 2003 \\
\hline $\begin{array}{l}\text { Hon. Olagunju, member OsunState House } \\
\text { of Rep. }\end{array}$ & Murdered & 2002 \\
\hline $\begin{array}{l}\text { Mr. Dele Anoja PDP Gubernatorial Aspirant } \\
\text { Lagos State }\end{array}$ & Murdered & 2002 \\
\hline
\end{tabular}

The above are cases of assassination, killings and attempts on the lives, religious/ethnic communal conflicts. This is unprecedented in the history of the country. The spate of the eruption of these communal conflicts, religious and ethnic conflicts made the Obasanjo's administration to brace up and face the challenges and avoid the risk of the military taking over power again. The response was brutal and in some cases extreme. The dispatch of soldiers to Odi in Bayelsa State and to Zaki-Biam in Benue State left soured memory of democracy in the country.

There is no doubt that the democratic transition gave the people room to vent their bottled-up frustrations. However, criminals seized that as opportunity to ply their trade under the guise of 'genuine' agitations.

In the Niger Delta, the unending crises have been linked to oil bunkering business in the area. The youths are now adopting terrorist tactics by kidnapping oil companies' workers and demanding ransom before their release.

\section{Vigilante Groups as Response to Crime Problem}

In the words of Gailand (2001) people device their own strategies to protect themselves from victimization. The response includes the setting up of vigilante groups.

We were able to obtain some crime report records from the vigilante groups. Three communities were selected and these communities happened to have existing vigilante groups. This they said was their communal effort to tackle the problem of crime in their communities. Each of these vigilantes is made up of between 20 to 150 memberships. In one of the communities women were members of the vigilante. We were told that these women play the role of informants. The age structure ranged between 17-45 years. The members were mostly, motorcycle operators common called 'In'aga', okada, achaba, farmers' artisans/craftsmen, junior civil servants, and unemployed school leavers. They have presidents/chairmen, vice presidents/vice chairman, secretaries, PROs, Treasurers and so on. They said that they rotate their members' days of operation. Some groups do between two days to one week and another group takes over. these vigilantes.

The researchers were able to carry out a Focus Group Discussion (FGD) with some of the members of

The report is presented below. This table below is a summed up record of crimes in the communities between 1999 and 2003.

Table 4.3c Statistics of Crime in Three Communities of Oguta, Umuaka and EgbuBetween 1999 to 2003.

\begin{tabular}{|l|l|l|l|l|l|l|l|l|l|l|}
\hline Year & Robbery & Stealing & Burglary & Murder & $\begin{array}{c}\text { House } \\
\text { Breaking }\end{array}$ & Kidnapping & $\begin{array}{c}\text { Child } \\
\text { Stealing }\end{array}$ & Arson & Rape & Total \\
\hline 1999 & 25 & 28 & 30 & 2 & 30 & 0 & 2 & 1 & 1 & 120 \\
\hline 2000 & 36 & 42 & 48 & 3 & 37 & 1 & 3 & 0 & 4 & 174 \\
\hline 2001 & 40 & 48 & 48 & 1 & 40 & 0 & 3 & 0 & 6 & 186 \\
\hline 2002 & 38 & 52 & 45 & 5 & 42 & 2 & 5 & 0 & 5 & 194 \\
\hline 2003 & 48 & 58 & 50 & 3 & 45 & 3 & 2 & 4 & 10 & 223 \\
\hline Total & 187 & 228 & 221 & 14 & 194 & 6 & 15 & 5 & 27 & 893 \\
\hline
\end{tabular}

Source: Adapted from records of the vigilante groups in the three communities from $1999-2003$.

From the table above, we can see that all the crimes have been on the increase except for child stealing and murder that showed a decline in the year 2003.

There were two murder reports in 1999 , however in 2002, it moved to 5 . The explanation for this could be attributed to the political activities the year 2002 was the year preceding the general election in the country. That year the state recorded some politically linked premeditated killings and assaults.

Two governorship aspirants in the state were reported shot by people they claimed were assassins. In the year 2002, two prominent politicians in the state were shot and killed in their homes by unidentified 
assassins. One was a former commissioner in the state and a senatorial aspirant and another was an adviser to the governor.

The trend allover the country was the same. That drew the attention of the highest law making body in the country. The senate Chairman on Police affairs, Senator NuhuAlihu in a motion he moved on the floor of the senate drew the attention of the senators on the spate of armed robbery in Lagos State. Speaking he said;

I am sure recently you hard about how many people were killed by armed robbers in Lagos. Managing Director of Equatorial Trust Bank was gunned down in his car, another Managing Director was seriously wounded. There was another Managing Director in another car who saw what was happening to his colleague and wanted to run away from the scene, but the armed robbers saw him and killed him. There was also another expatriate, the General Manager of R.T. Briscoe who was highly molested, kidnapped, taken out of his car and squeezed inside a car boot and driven away by armed robbers and later abandoned. All these happed in Lagos State.

This account by an Honourable senator goes to show that crime especially armed robbery in the country has taken serious dimension. The House of Representatives recently passed a resolution calling on the Federal Government to procure helicopters for police formation across the country to help them in fighting crimes especially armed robbery. And to reintroduce a joint police military patrol.

From the survey carried out by the researchers, they discovered that those in the business of making and selling of metal doors and windows have been making good sales. According to one of the metal doors and windows fabricator; he said that people are now going for metal doors because they are more secured. They are good protectors to their houses. Another told us that some that had wooden doors are changing them to metal doors or fortifying them with iron protectors. One building contractor told the researcher that people building houses now are more security conscious. He said that more people go for high wall fence, metal doors at every entrance to the building, windows with iron protectors and other security devices.

The researcher also discovered that some streets have gates. These gates are usually closed around 10:00 pm and opened early the next morning. In one of the towns, the people installed gates on the road that leads into the two. According to the leader of the vigilante group of the town, he said that the gate was installed do to the menace of armed bandits that were terrorizing the people.

All these are borne out of the feeling of insecurity among the people. The insecurity problem in the state made the Imo State House of Assembly to pass a resolution, asking the Governor of the state to introduce a vigilante group into the state as obtains in the neighbouring states like Abia and Anambra to fortify the security of the lives and properties of the citizens.

From the study we can say that since the democratic transition, the feeling of insecurity has increased among the people. And there has been an increased media report on crime. Going by statistics of crime by other bodies other than police than the police, crime rate has increased the country since 1998 . There has been an increase occurrence of pre-meditated killing, especially of people with political lining since 1998 till date.

Also, the period under consideration has witnessed an increased proliferation of militant vigilante groups across the country. The reckless and gruesome activities of these vigilante groups have been documented by scholars (see OkechukwuNwanguma, 2002).

The poor economic situation in the country with the attendant high level of poverty, the rapid urbanization, the disorganization in the traditional and cultural norms and values of the people, the effects of globalization can be said to have contributed to the high crime rate in the country. The struggle by the people for democratic rule paid off. The expectations were high. The euphoria soon weaned out and frustration and anger set in, the adjusting and aligning for new power blocs caused frictions among the politicians. This could be the reason for the pre-mediated killings of some people with political lining across the country.

It is our position that no single factor can perfectly explain the high rate of crime in transiting society like Nigeria. The explanation should be situated in the history, economic, social and the global position of the country.

\section{References}

[1]. Adedokun, S (1990) "External Constraints on Democratic Process and Practices in Underdeveloped Countries. A Case of the IMF Interventions in Nigerian Politics" Studies in Politics in Society. P; 87-96

[2]. Agbese, P.O. (1990) "The Impending Demise of Nigeria's Fourth Coming Third Republic" Africa Today $37(3)$; 233 - 441

[3]. Ahmed, A (1997) The World Bank and Nigeria .Kaduna: Baraka Press.

[4]. Ake, C (1981) The Political Economy of Africa, Nigeria Longman

[5]. Ake, C.(1988) "The Political Economy of Development" International Science Journal 118: 485-497

[6]. Alemika, E.O (1983) "The Nature of Crime in Nigeria" (Unpublished)

[7]. Alemika, E.O (1993b) Law on Social Change, Netherlands: Kluwer Academic Publishers

[8]. Alemika, E.O (1998) Recession and Repression in Nigeria Jos: African Centre for Democratic Governance

[9]. Alubo, O. (1989) "Crisis, Repression and the Prospect for democracy in Nigeria" Scandinavian Journal of Development Alternatives V 11-4: 107-122

[10]. Alubo, O. (1990) "Human Rights and Militarism in Nigeria" In G.

[11]. Shepherd and M. Anikpo Emerging Human Rights: The African Political Economy Context. Pp. 179 - 207 
[12]. Bangura, Y. (1987) "Structural Adjustment and Political Question Review of African Political Economy 37:224 - 337

[13]. Barlow, Hugh D. (1981) Introduction to Criminology ( nd $^{\text {nd }} E$ d.) Little Brown and Company. Boston, Toronto, U.S.A.

[14]. Barnes, H.E. \& Tecters, N. K. (1943) New Horizons in Criminology. Englewood Cliffs: Prentice-Hall

[15]. Bonger, Willem (1968) Criminality and Economic Conditions Indiana University Press.

[16]. Clinard, M.B. (1968) Sociology and deviant Behaviour. New York: Holt, Rinehart and Winston

[17]. Cohen, S. (1996) "Crime and Politics: Spot the Difference" Journal of Sociology.Vol. 47, no. 1, March.

[18]. Danmadami, M. (1979) "The Role of the Police in Maintaining Law and Order" in E. O. Akeredolu-Ale et al (Ed).Social Problems and Criminality in Nigeria.

[19]. David, Downes\& Paul Rock (1998) Understanding Deviance: A Guide to the Sociology of Crime and Rule Breaking $\left(2^{\text {nd }}\right.$ Ed). Oxford: Clarendon Press.

[20]. Dele Olowu et al (Ed) (1995) Governance and Democratisation in Nigeria. Owerri: Spectrum Publishers

[21]. Dixon, B. (2000) "Cloud over the Rainbow: Crime and Transition in South Africa" source:www.iss.org.za/

[22]. Lars Rudeback, et el (1998) (Ed) Democratization in the Third World: Concrete Cases in Comparative and Theoretical Perspectives, New York: Macmillian Press

[23]. Mohammed Garba (2002) "Unemployment: A Threat to Democracy in Nigeria" (Unpublished)

[24]. Nabudere, D. (2000) "Globalization, the African Post-Colonial State, Post-traditionalism, and the New World Order" in Nabudere, D. (Ed) Globalization and the Post-Colonial African State, Harare: AAPS pp 11-55

[25]. Olagunji, T. et el (1993) Transition to Democracy in Nigeria Ibadan; Safari Books.

[26]. Sokunbi-Eboetel (2000) "The Emergence of Militant Ethnic Groups: a Threat to Democracy (Unpublishes)

[27]. Sutherland, E.H. (1947) Principles of Criminology LippinCottCo

[28]. Taylor, I. et al (1973) The New Criminology New York, Haper and Row

[29]. Wolfgang, M.E. et el (1962) (Ed) The Sociology of Crime and Delinquency, New York: John wiley and sons.

[30]. (1999) "No Electiom in Bayelsa". The Guardian January 7; 1 -2

[31]. (1999) "EkitiMilad Orders Arrest of APP Candidate" The Guardian, January, 10.p 3

[32]. (1999) Government Deployed two Warships to Bayelsa" The Guardian, January, p

[33]. (2002) “Traders Protest Killing by Bakassi Boys' Punched, March 29

[34]. (2002) 'Police Kill 10 rubbers; Arrest 30 suspects in Rivers State

[35]. (2002) "Bandits Kill 17 Cops, 68 others in North-East"

[36]. New Nigeria, February, 10. (2002) " 38 Lives Lost in Taraba" Guardian, January 8

[37]. (2002) "100 Feared Killed in Nassarawa Communal Clash" Guardian, January, 10

[38]. (2002) " 35 Houses Burnt 44 Killed in Clashes Between Palace Guards and OPC" Punch, January, 14

[39]. (2002) "100 Feared Dead in Lagos Clashes" Punch, February 16

[40]. (2002) "Soldiers Sack Town, Raze 60 Houses in Bayelsa" This Day, February 8

[41]. (2002) "7 Policemen Killed in Danji, Government Begins Probes" Punch, February 10

[42]. (2002) "Police Arrest 18 Yandaba" New Nigeria 16

[43]. (2002) "Communal Clash Claims lives, Properties" New Nigeria February 26

[44]. (2002) Three Killed in Clash With Police in Ilorin" Guardian February 26

[45]. (2002) "Ika Communal Clash FG Deploys Soldiers" Punch February 3

[46]. (2002) "Ten Killed in Communal Feud" Punch February 28

[47]. (2002) "10,000 Tiv Refugees Return to Taraba” New Nigeria March 20

[48]. (2003) "Elections 83 Killed, 159 Injured" The Punch June 20 p 9

[49]. (2003) "Upsurge in Crime Blamed on Political Thugs" The Punch June 23 p 12

[50]. Equal Justice Vol. 4 No. 11 April 2002.

[51]. Human Rights Situation Report, January - March, 2003

[52]. Liberty, Vol. 11 No. 5 September 1999

[53]. Liberty Vol. 12 No. 8 September 2000 